\title{
Streptozotocin is not toxic to the human fetal B Cell
}

\author{
B.E. Tuch ${ }^{1}$, J.R. Turtle ${ }^{1}$ and C.J.Simeonovic ${ }^{2}$ \\ ${ }^{1}$ Department of Medicine, University of Sydney, Syndey and ${ }^{2}$ The Transplantation Biology Unit, Division of Clinical Sciences, John Curtin \\ School of Medical Research, Australian National University, Canberra, Australia
}

\begin{abstract}
Summary. It has been generally assumed that because streptozotocin is toxic to the adult B cell of most species, it should also damage $B$ cells obtained at earlier stages of development. This paper examines whether this is true for human fetal pancreata obtained from the therapeutic termination of pregnancies during the first half of the second trimester. Experiments were carried out both in vivo and in vitro. For the former experiments diced explants of the human fetal pancreas were grafted beneath the renal capsule of nude mice 3 weeks before streptozotocin was administered to make the animals diabetic. The grafts were removed 1 week, 2-4 weeks or 3 months later, and were found to be of similar weight and insulin content to the control grafts. In 2 of the animals with grafts remaining for 3 months the diabetes had even been reversed by the implant, hyperglycaemia recurring when the graft was removed. In contrast, rat fetal pancreata grafted beneath the renal capsule of nude mice, subsequently rendered diabetic, were adversely affected by streptozotocin, the insulin content of the implants
\end{abstract}

being $12 \%$ of levels in control grafts. Adequate uptake of streptozotocin by the implanted human fetal pancreas was established by measuring tissue levels of the drug $30 \mathrm{~min}$ after its injection. Histological examination of the grafted human fetal pancreas showed no deleterious effect of streptozotocin on the number of granulated B cells one day after injection, although by this time the host was diabetic. In vitro, streptozotocin had no effect on insulin release from the cultured human fetal pancreas, whereas a toxic effect on adult mouse islets was observed. In summary, these data show that streptozotocin has no demonstrable diabetogenic effect on the human fetal $B$ cell, a situation comparable to the lack of chemotherapeutic effect of this drug in many patients with malignant insulinomas, which morphologically and functionally have some similarities with the human fetal pancreas.

Key words: Streptozotocin, human fetal pancreas, nude mice, islets, insulin content, insulin release.
Unlike the adult pancreas the fetal pancreas is an immature organ that releases little or no insulin in response to a glucose challenge [1-6]. The ability of the fetal B cell to respond to streptozotocin, an analogue of glucose - glucose and methylnitrosourea, is not known. We hypothesized that this agent would not adversely affect the immature $B$ cell, as opposed to its well known toxic effect on the adult B cell. Such toxicity is manifest within a matter of hours in vivo [7] and is evident in a wide variety of species - mouse, rat, hamster, dog, monkey [8] and pig [9], although there are a number of exceptions [10]. After $30 \mathrm{~min}$ of exposure to this agent in vitro there is an immediate decrease in insulin synthesis in the adult islet [10] and a reduction of insulin release within days [11]. Streptozotocin does have adverse effects on the neonatal $\mathrm{B}$ cell of the rat $[12,13]$, but this is not as severe as that produced in the adult cell, there being regeneration of $B$ cells [12].

The effect of streptozotocin on the human fetal pancreas was examined both in vivo and in vitro. For the former experiments streptozotocin was administered to nude mice that had been grafted with explants of human fetal pancreas. Previously, we have demonstrated that these mice can be successfully used as reci- pients of this tissue, with both growth and an increase in insulin content resulting [14]. In the current experiments weight and insulin content of the graft, together with ability to normalize glucose levels, were the parameters monitored in treated and control animals. Prior experiments have established the validity of these parameters in monitoring the effect of a toxin [15]. Histological studies were also performed to measure the number of $B$ cells. The effect of streptozotocin in vitro was examined by adding it to cultures of either human fetal pancreas or adult mouse islets, the latter serving as a positive control.

\section{Materials and methods}

\section{Human fetal pancreata}

These were acquired from the therapeutic termination of pregnancies at $14-18$ weeks gestation after maternal consent for the use of the tissue had been obtained. Ethical approval was granted by the Ethics Committees of the University of Sydney and the attached major teaching hospital, Royal Prince Alfred Hospital. Terminations were carried out by suction curettage, tissue being obtained within $4 \mathrm{~h}$ of this procedure. The fetal pancreata were diced into one $\mathrm{mm}^{3}$ explants and placed overnight in organ culture at an air-liquid interface as pre- 
viously described [17]. Culture medium used was RPMI 1640 supplemented with amino acids, antibiotics, and human stable plasma protein solution [17].

\section{Animals}

Male swiss nude mice were obtained from the Animal Resource Centre (Murdoch, Western Australia, Australia). They were given sterile chow and water ad libitum. Inbred male BALB/c mice, 8 weeks old, were obtained from the Animal Breeding Establishment, John Curtin School of Medical Research, Canberra, Australia.

\section{Transplantation of human fetal pancreas}

After anaesthesia was induced in the nude mice with $70 \mathrm{mg} / \mathrm{kg}$ phenobarbitone, the left kidney was exposed through a flank incision. The renal capsule was surgically cut and explants of human fetal pancreas placed with forceps beneath the capsule. This tissue was then gently massaged towards the hilum. Closure was in two layers, $4 / 0$ catgut being used for the peritoneal incision and $4 / 0$ silk for the skin.

The mice were grouped in pairs, each animal receiving a similar amount of tissue from the same fetal pancreas as its pair (mean \pm SD: $5.4 \pm 1.8 \mathrm{mg}$ tissue per animal).

\section{Induction of diabetes}

Streptozotocin at a concentration of $275 \mathrm{mg} / \mathrm{kg}$ was injected i.p. to one animal of each of the 18 pairs of mice 18-21 days after the tissue was engrafted. A second dose of $300 \mathrm{mg} / \mathrm{kg}$ streptozotocin was required to be administered to 2 of these mice one week later, in order to render them diabetic. Glucose levels were measured on blood collected from the tail vein using glucose reagent strips and a glucometer (Boehringer Mannheim Reflolux II, Mannheim, FRG). The mean \pm SEM level of whole blood glucose in these mice was $21.0 \pm 1.1 \mathrm{mmol} / 1(n=18)$, compared with $6.0 \pm 0.3 \mathrm{mmol} / 1(n=18)$ in the control mice, to whom $0.1 \mathrm{~mol} / \mathrm{l}$ acetic acid was administered.

\section{Insulin content}

Each pair of grafted mice was killed 1 week, 2-4 weeks or 3 months after the administration of streptozotocin. The human implants and mouse pancreata were removed for weighing and estimation of insulin content, the former being shelled out from beneath the renal capsule. For this purpose the tissue was homogenized with 1 or $2 \mathrm{ml}$ Wheaton tissue grinders in acid ethanol $(18 \mathrm{ml}$ of $10 \mathrm{~mol} / 1 \mathrm{HCl} / 1$ of $70 \%$ ethanol), and insulin extracted overnight from the homogenate at $4^{\circ} \mathrm{C}$. The supernatant was then removed and stored at $-20^{\circ} \mathrm{C}$ until it was assayed for insulin by conventional radioimmunoassay (porcine standard, antiserum IN-40 from Endocrine Sciences, Tarzana, Calif., USA).

\section{Transplantation of rat fetal pancreas}

Pancreata were removed from fetuses of 3 Manchester hooded rats at 17-21 days gestation. The organs were mixed, divided into 11 even groups, and grafted beneath the renal capsule of 11 nude mice, as described above for human fetal pancreas. Of these animals 5 were injected with $275 \mathrm{mg} / \mathrm{kg}$ streptozotocin 3 weeks after engraftment, the remaining 6 receiving citrate alone. All animals were killed 1 week after being injected and the weight and insulin content of the grafts determined. Measurement of insulin was performed by radioimmunoassay that utilized a rat standard (Novo Biolabs, Bagsvaerd, Denmark).

\section{Uptake of streptozotocin}

In order to be certain that the human fetal pancreas, with its B cells, grafted in the mice was being exposed to the streptozotocin, tissue levels of the drug were measured. Human fetal pancreatic explants were grafted beneath the renal capsule of 6 nude mice and remained in these animals for 14-20 days. These mice were then killed 25 min after i.p. injection of $275 \mathrm{mg} / \mathrm{kg}$ streptozotocin, and the implant and a number of murine organs (pancreas, liver, spleen, kidney, lung) removed. The tissues were homogenized in $0.6 \mathrm{~mol} / 1$ perchloric acid and the supernatant removed for estimation of streptozotocin. For comparative reasons explants of human fetal lung and kidney were also grafted beneath the renal capsule of a further 4 nude mice, streptozotocin being injected after 18 days, and the implants and mouse organs removed for chemical analysis 25 min later.

\section{Measurement of streptozotocin}

Streptozotocin was measured by spectrophotometry [18], an intact Nnitroso portion of the molecule being required for this technique to be successful [19]. Previous studies have shown this procedure to be a suitable method for measuring tissue levels of streptozotocin [18], there being $20 \%$ of an i. v. injected dose of $200 \mathrm{mg} / \mathrm{kg}$ streptozotocin in the liver at $30 \mathrm{~min}$ [18]. The standard curve for streptozotocin was linear in the range $2-100 \mu \mathrm{g} / \mathrm{ml}(\mathrm{y}=0.02 \mathrm{x}-0.002 ; r=0.9998)$.

\section{Histological examination}

Explants of 2 human fetal pancreata, gestational age 14-15 weeks, were grafted beneath both renal capsules of 2 nude mice, 4 implants being grafted in total. One animal was rendered diabetic 3 weeks later with $300 \mathrm{mg} / \mathrm{kg}$ streptozotocin (blood glucose $19.5 \mathrm{mmol} / \mathrm{l}$ ), the second animal receiving solvent alone (blood glucose $4.3 \mathrm{mmol} / \mathrm{l}$ ). The animals were killed $24 \mathrm{~h}$ after being injected, the grafts removed, embedded in paraffin and analysed histologically with insulin antibody (Dako Corporation, Santa Barbara, Calif., USA) and an immunoperoxidase stain. From each implant 3 sections $20 \mu \mathrm{m}$ apart, were cut, and analysed blindly by one person for B cells. Approximately 2000 epithelial cells were counted in each section, the number of $B$ cells being expressed as a percentage of the total.

\section{Effect on cultured human fetal pancreas}

Explants of human fetal pancreas, cultured as described above, were exposed for $30 \mathrm{~min}$ to $4.4 \mathrm{mmol} / \mathrm{I}$ streptozotocin. This concentration was made by dissolving $117 \mathrm{mg}$ of the drug in $0.5 \mathrm{ml}$ citrate buffer and diluting it 1:100 in regular culture medium. The control grafts were exposed to $1 \%$ citrate buffer added to the culture medium. At regular intervals thereafter for 2 days, culture medium was replaced with fresh medium. The samples were stored until assayed for insulin.

\section{Effect on cultured adult mouse islets}

Islets from adult $\mathrm{BALB} / \mathrm{c}$ mice were obtained by collagenase digestion and hand picking as described previously [17]. They were placed in batches of 25 in the U-shaped wells of a 96 multiwell plate (Linbro, Flow Laboratories, McLean, Va, USA). The medium used was RPMI with $10 \%$ fetal calf serum (gassed with ambient air and $5 \% \mathrm{CO}_{2}$ ) until $3 \mathrm{~h}$ before exposure to streptozotocin; thereafter the medium used was that described above for use with the human fetal pancreas. Exposure to $4.4 \mathrm{mmol} / 1$ streptozotocin was for $30 \mathrm{~min}$. At regular intervals over the following 6 days the medium was renewed, samples being stored for measurement of insulin. This experiment was carried out after that for cultured human fetal pancreas, and was by design of a longer duration. Had an effect of streptozotocin been observed only after 2 days, it would have been necessary to repeat the culture with human fetal pancreas for a longer period of time. 


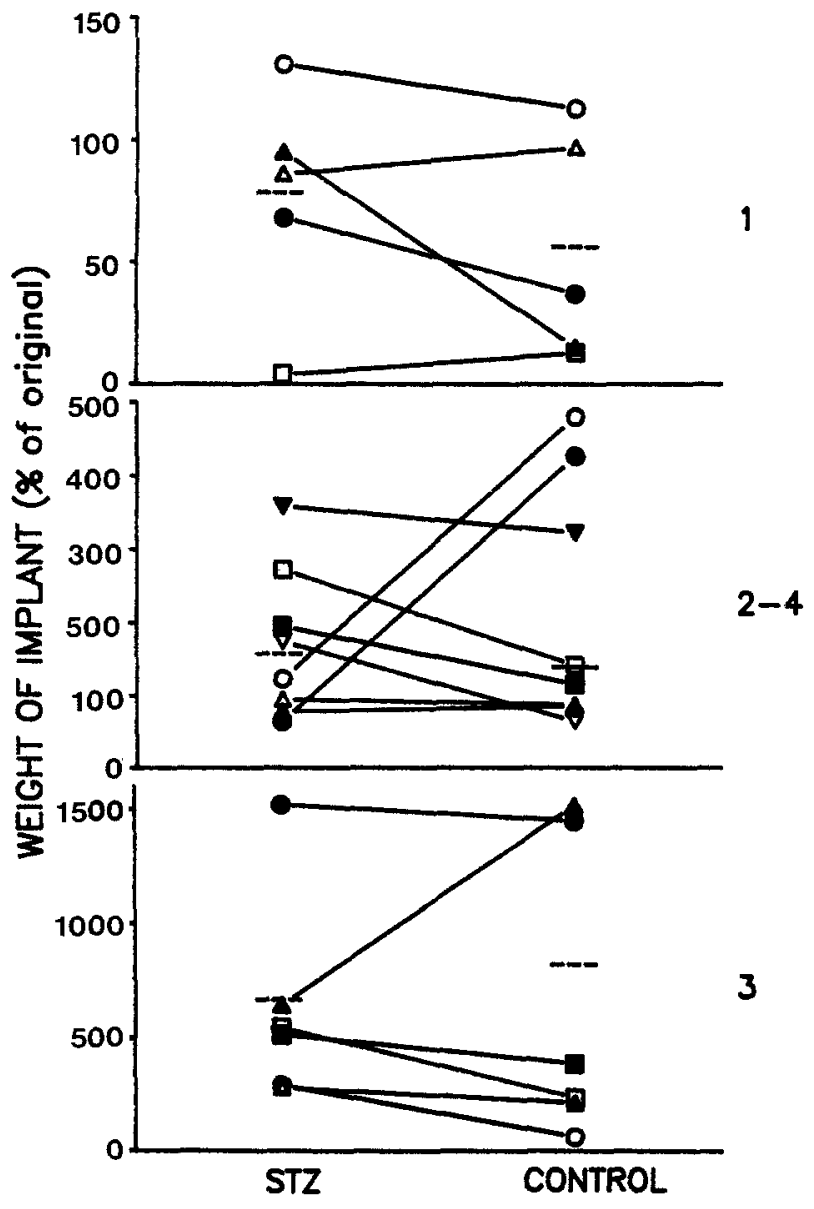

Fig. 1. The weight of human fetal pancreatic implants removed from beneath the renal capsule of nude mice, 1 week, 2-4 weeks or 3 months after injection of streptozotocin (STZ). Control animals were not injected. Values have been expressed as a $\%$ of the original weight. The lines connect the values obtained for each pair, one animal receiving tissue and 3 weeks later being injected with streptozotocin, and the other (the control) an approximately equal amount of the same fetal pancreas, but not made diabetic. The dotted lines represent the median values. There were no significant differences between any of the treated and control groups

\section{Statistical analysis}

Data from the nude mouse experiments was analysed non-parametrically using the Mann-Whitney U test. Paired t-testing was not possible because of the difference in variances between the groups. Those from the cultures were analysed using a customized version of the repeated measures multivariate analysis of variance on BMDP [21], as occurs in the $4 \mathrm{~V}$ programme.

\section{Results}

\section{Human fetal pancreas grafted in nude mouse}

Streptozotocin was not toxic to the transplanted human fetal pancreas, as assessed by its weight and insulin content after removal from the recipient mouse (Fig. 1 and 2). This was irrespective of the time after administration of streptozotocin that the graft was removed - 1 week, 2-4 weeks or 3 months. In contrast, streptozotocin was

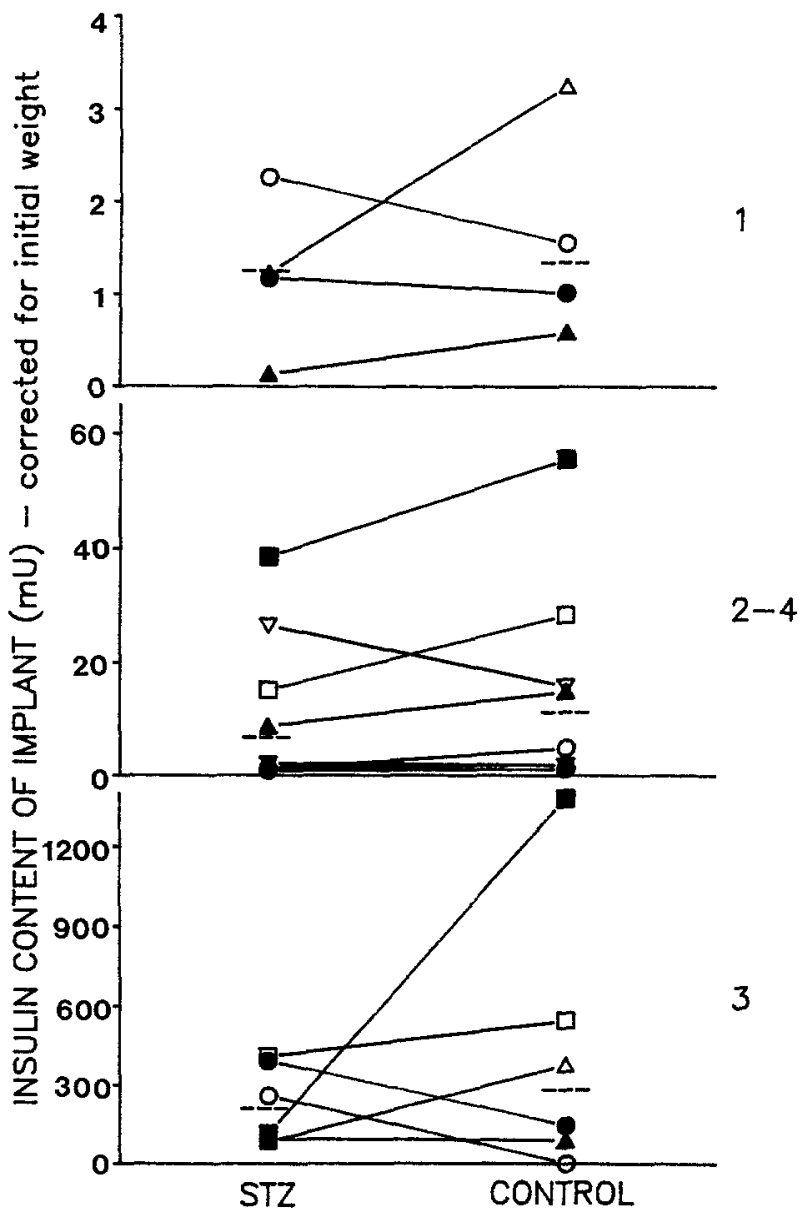

Fig. 2. Insulin content of human fetal pancreatic implants removed from beneath the renal capsule of nude mice, 1 week, 2-4 weeks or 3 months after injection of streptozotocin (STZ). Control animals were not injected. These values $(n=16)$ have been corrected to equalize the commencing weights in each pair - there were minor differences between the untreated $(5.42 \pm 2.03 \mathrm{mg})$ and the treated tissue $(5.22 \pm 1.53 \mathrm{mg})$. The lines connect the values obtained for each pair, as explained in the caption for Figure 1 . The dotted lines represent the median values. There were no significant differences between any of the treated and control groups

toxic to the rodent $\mathrm{B}$ cell, with all animals injected becoming diabetic and the insulin content of their pancreata being significantly less than that of the controls (Fig.3).

Of the 6 diabetic animals grafted with human fetal pancreata for 3 months 4 became normoglycaemic (blood glucose $4.2 \pm 0.8 \mathrm{mmol} / \mathrm{l}$ ) during this period, 3 between 10 and 12 weeks and one 4 weeks after streptozotocin was administered. The implant and left kidney were removed from 3 of these animals 3 days prior to the mouse being killed and its pancreatic insulin content estimated. The blood glucose level became elevated again in 2 of these animals $(20.3 \pm 5.5 \mathrm{mmol} / \mathrm{l})$; in the third animal the blood glucose remained normal. It was in this last animal, which had been rendered diabetic by streptozotocin (blood glucose $15.4 \mathrm{mmol} / \mathrm{l}$ ), that B cell regeneration in the murine pancreas was likely to have occurred, a phenomenon described previously in rodents after streptozotocin administration [22]; the in- 


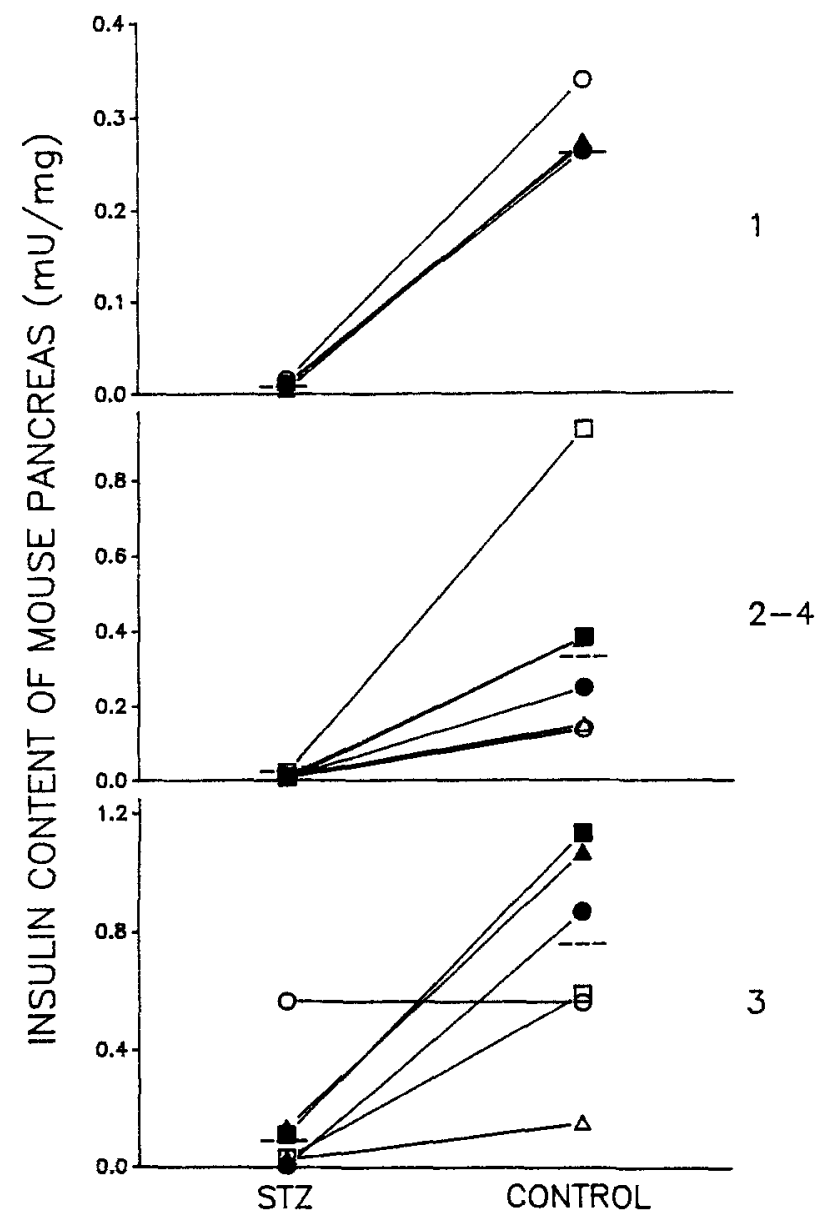

Fig.3. Insulin content of mouse pancreata 1 week, 2-4 weeks or 3 months after injection of streptozotocin (STZ). Control animals were not injected. Values have been expressed as $\mathrm{mU} / \mathrm{mg}$. The lines connect the values obtained for each pair, as explained in the caption for Figure 1. The dotted lines represent the median values. Control groups contained significantly more insulin than the treated groups $(P<0.05)$

sulin content of the rodent pancreas was the same as the control animal $(0.57 \mathrm{mU} / \mathrm{mg}$ diabetic; $0.56 \mathrm{mU} / \mathrm{mg}$ control) (Fig.3). Analysis of the pancreatic insulin content of all diabetic mice, in whom graft tissue remained for 3 months, revealed further evidence of probable $B$ cell regeneration in that significantly greater values were obtained from these animals than from those mice in whom the graft tissue remained for shorter periods median 0.07 vs $0.01 \mathrm{mU} / \mathrm{mg}, p<0.05$. The same was not true for the pancreatic insulin content of the nondiabetic animals.

\section{Rat fetal pancreas grafted in nude mouse}

In contrast to the lack of effect of streptozotocin on grafted human fetal pancreas, this drug was toxic to the rat fetal pancreas, of gestational age 17-21 days, that was grafted into nude mice subsequently made diabetic. The insulin content of this rodent tissue one week after administration of a dose of streptozotocin, which was diabetogenic for the adult recipients (blood glucose $23.1 \pm 1.7 \mathrm{mmol} / 1$ ) was $0.20 \pm 0.11 \mathrm{mU} / \mathrm{mg}, n=5$. This was $12 \%$ of the insulin content of implants $1.65 \pm 0.27 \mathrm{mU} / \mathrm{mg}, n=6$ - grafted into animals that were injected with buffer alone (blood glucose $4.4 \pm 0.2 \mathrm{mmol} / \mathrm{l})$.

\section{Uptake of streptozotocin}

There was more streptozotocin per mg tissue in the grafted human fetal pancreas, $4-10 \%$ of which were $B$ cells [23] than in any of the murine organs examined (Table 1). Of the rodent tissues examined, the liver and kidney, organs concerned with the metabolism of streptozotocin [24], contained more of the drug than either pancreas ( $\mathcal{A} \% \mathrm{~B}$ cells) or spleen. This selectivity of the human fetal pancreas for this drug was not related to the site of grafting, since other human fetal tissues (lung and kidney) implanted at the same site showed poor uptake (Table 1).

\section{Histology of grafted human fetal pancreas exposed to streptozotocin}

One day after administration of a diabetogenic dose of streptozotocin to the nude mouse, that had been engrafted 3 weeks previously, there was no significant difference from controls in the percentage of $\mathrm{B}$ cells in the grafts (Fig.4). Of the 11,000-14,000 epithelial cells counted, $10.4 \pm 1.3 \%$ were B cells in the streptozotocintreated group $(n=6)$, and $7.6 \pm 0.9 \%$ in the control group $(n=6)$.

\section{In vitro effect of streptozotocin}

Streptozotocin had no deleterious effect on the ability of the human fetal pancreatic explants to release insulin in organ culture for $50 \mathrm{~h}$ after exposure to the drug (Fig.5). In contrast, a toxic effect on the adult B cell could be demonstrated during a similar period of time

Table 1. Tissue levels of streptozotocin $25 \mathrm{~min}$ after its i. p. administration - $275 \mathrm{mg} / \mathrm{kg}$ (range $6.2-7.4 \mathrm{mg}$ per mouse) - to nude mice that had previously been transplanted with human fetal tissue - pancreas, lung or kidney. The values have been expressed as $\mu \mathrm{g} / \mathrm{mg}$ tissue. Liver and kidney taken from mice not given streptozotocin had undetectable levels of this drug

\begin{tabular}{lccc}
\hline Tissue & mean & $\pm \mathrm{SD}$ & $\begin{array}{l}\text { no of } \\
\text { recipients }\end{array}$ \\
\hline Human fetal pancreatic implant & 0.71 & 0.22 & 6 \\
Human fetal lung/renal implant & 0.08 & 0.03 & 4 \\
Mouse pancreas & 0.14 & 0.07 & 10 \\
Mouse liver & 0.53 & 0.19 & 10 \\
Mouse kidney & 0.44 & 0.16 & 10 \\
Mouse spleen & 0.08 & 0.02 & 7 \\
Mouse lung & 0.15 & 0.12 & 4 \\
\hline
\end{tabular}




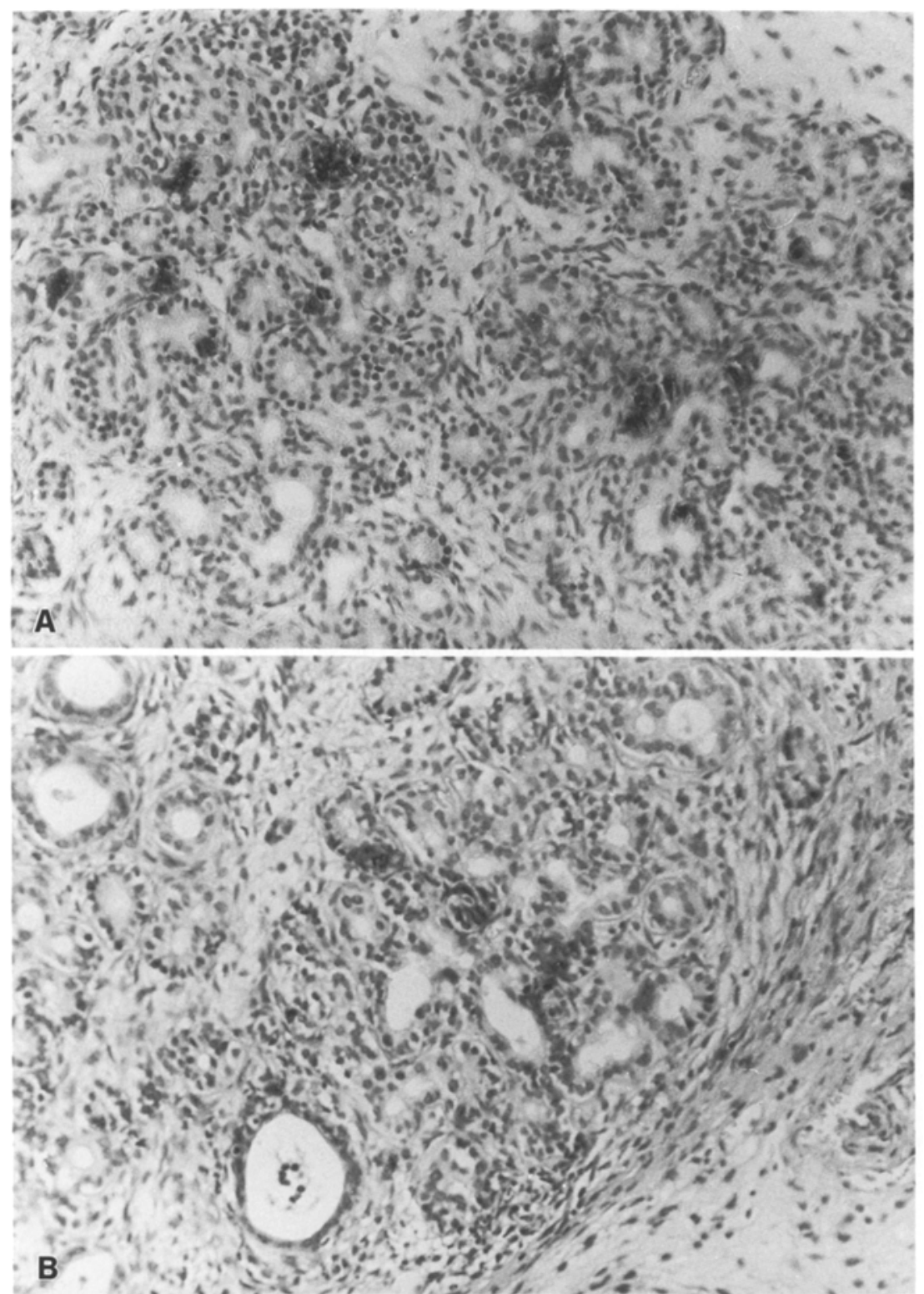

Fig. 4A, B. B cells (dark stain) in human fetal pancreas grafted for 3 weeks beneath the renal capsule of the nude mouse, before being made diabetic with streptozotocin. The grafts were removed 1 day after injection of this toxin. There was no difference in the number of $B$ cells in the grafts of the treated A vs the control animal B. Immunoperoxidase stain for insulin, X 200 after exposure of adult mouse islets to the same concentration of the drug ( $p=0.0008$ ) (Fig. 6). Culture of these islets, that had been exposed to streptozotocin, for a further 3 days resulted in continued significant inhibition of insulin release $(p=0.0002)$. In contrast, in both the human and murine experiments, there was no significant difference in insulin release between the control and the treatment group, before exposure to streptozotocin.

\section{Discussion}

These data show that streptozotocin is not diabetogenic to the human fetal pancreas in vivo nor does it affect insulin release from this tissue in vitro. These results contrast with the well established effect of streptozotocin on the adult $B$ cell both in the living animal $[7,8]$ and in culture $[10,12]$. They differ from the toxic effect ob- served by us on rat pancreas, matured for 3 weeks in vivo before exposure to streptozotocin, as well as from its effect on rodent pancreas obtained immediately after birth $[13,14]$. In this last case B cells are destroyed within $24 \mathrm{~h} \mathrm{[25];} \mathrm{by} 4$ days there is regeneration of some $B$ cells, but the function of these is distinctly abnormal [13]. Whether the data obtained with the human fetal pancreas are applicable to fetal pancreas of other species is conjectural. There are no reports of streptozotocin being given either to a pregnant rodent soon after the appearance of the pancreas in the embryo at around 10 days gestation, or to larger animals such as dog or pig at an equivalent stage in pregnancy as the human fetal pancreata used in these experiments. Streptozotocin has been given to pregnant rodents on days 3-5, before the appearance of the pancreas, with resultant reduction of insulin release from the embryonic pancreas that subsequently formed [26], a situation different from that reported in this manuscript. 
Why the human fetal pancreas should be so resistant to the effect of steptozotocin is unclear. Since this drug contains a glucose molecule, and glucose causes little if any insulin release from human fetal pancreas early in the second trimester [1-6], it is possible that the fetal $\mathrm{B}$ cell is not recognizing the drug. The theory is consistent with the claim in the adult that streptozotocin is selectively toxic to the B cell because of the presence of glucose [27]. It is also consistent with the lack of effect of streptozotocin on a clone of rat insulinoma cells, that are unresponsive to glucose [28]. An alternative explanation is the different redox state of pyridine nucleotides and glutathione in fetal islets, at least in the rat, with resultant lower activity of the pentose phosphate pathway [29]. In the adult islet streptozotocin inhibits this latter pathway [30]. It has been postulated that this action of streptozotocin, combined with a lowering of the absolute levels of NAD, as a result of stimulation of the chromatin-associated enzyme poly(ADP-ribose) synthetase by DNA breakage [31] and alkylation of vital enzymes [32], is the reason for the toxicity of streptozotocin to the adult islet [14]. It is also possible that the lack of effect of streptozotocin on the human fetal pancreas represents a lack of effect of this toxin on human $B$ cells, since adult human islets are not affected in vitro [33] and patients with malignant insulinomas treated with this agent do not develop diabetes [34]. Our studies do not rule out a possible deleterious effect of streptozotocin on insulin synthesis, an effect which is observed within hours of exposure to this agent in the adult rodent islet [11].

The data reported in this manuscript have possible relevance to two unrelated clinical situations. Firstly, they demonstrate that the human fetal pancreas, removed from its physiological situation and transplanted into an animal that is rendered diabetic, is capable of reversing the hyperglycaemia of the animal. Further experiments of this kind have confirmed similar results in larger numbers of animals [35]. This potential of the grafted human fetal pancreas has relevance to the clinical situation of reversing diabetes in humans with transplanted human fetal pancreata.

Secondly, the lack of effect of streptozotocin on the human fetal pancreas has similarities to the lack of response to this drug in $50 \%$ or more of patients with malignant islet cell tumours who are treated chemotherapeutically with this agent $[27,36,37]$. Such tumours show some morphological features that are characteristic of fetal pancreas, in particular numerous ducts, with endocrine cells budding from them [37]. Functionally, also, they are comparable in that both tissue types respond poorly to a glucose challenge [38]. The more malignant the insulinoma, the less differentiated it is histologically $[38,39]$ and the more abnormal is the control of the release of insulin, for example, suppression by somatostatin or diazoxide [39]. Indeed there have been attempts made to correlate clinically inhibition of insulin secretion by somatostatin with prospective responsive-

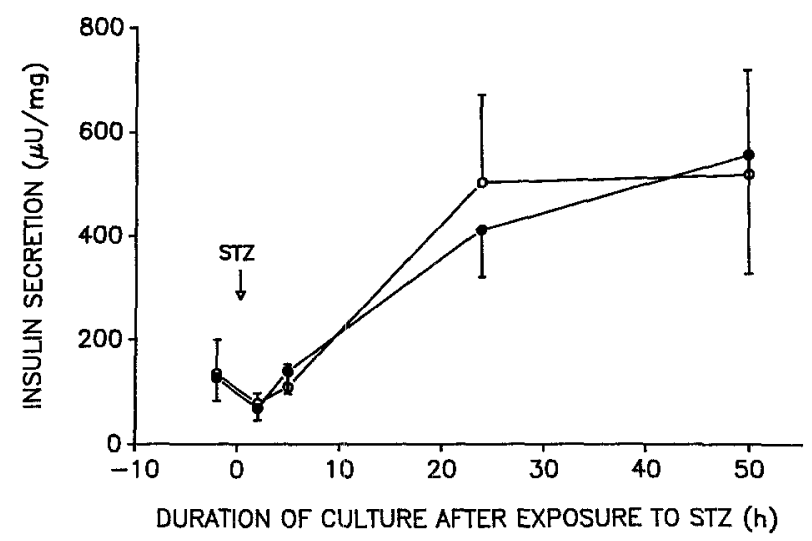

Fig.5. Insulin release from cultured human fetal pancreatic explants before and for $50 \mathrm{~h}$ after $30 \mathrm{~min}$ of exposure to $4.4 \mathrm{mmol} / 1$ streptozotocin (STZ) made up in 1\% citrate buffer. The control tissue was exposed to the same concentration of citrate buffer. Values (mean $\pm S D$, $n=6$ in each group) have been expressed as $\mu \mathrm{U} \cdot$ change of culture $^{-1} \cdot \mathrm{mg}_{\text {tissue }}-1$. There was no significant difference between the treated $\left(\mathrm{O}_{-} \mathrm{O}\right)$ and control groups $(0$

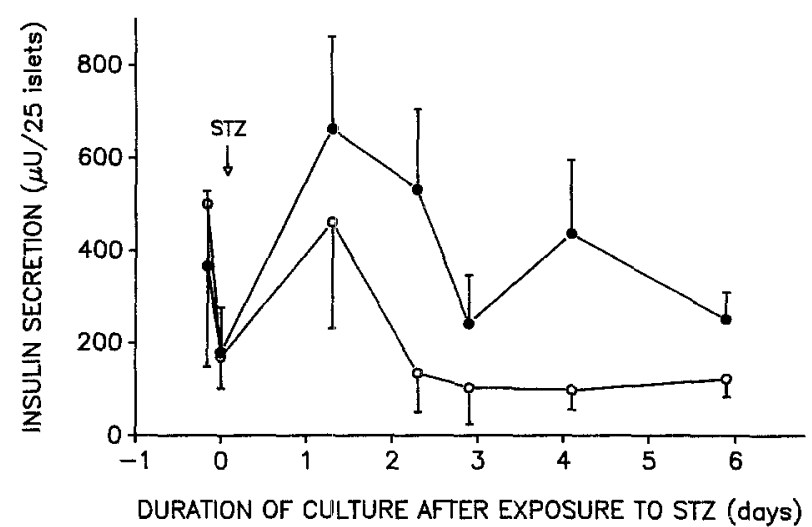

Fig. 6. Insulin release from cultured adult mouse islets before and for 6 days after $30 \mathrm{~min}$ of exposure to $4.4 \mathrm{mmol} / 1$ streptozotocin (STZ) made up in $1 \%$ citrate buffer. The control islets were exposed to the same concentration of citrate buffer. Values (mean $\pm \mathrm{SD}, n=6$ in each group) have been expressed as $\mu U$. change of culture ${ }^{-1} .25$ islets $^{-1}$. Treated islets released less insulin after exposure to streptozotocin $(\mathrm{O}-\mathrm{O})$ than the control islets (- up to day 2: $P=0.0008$; after this time: $p=0.0002$

ness to streptozotocin [39]. Exposure of human fetal pancreas to growth hormone results in maturation of the organ to release insulin in response to glucose [40]. If such transformation were to be accompanied by responsiveness to streptozotocin, then similar manipulations might be applied to B cell tumours in humans, in the hope that streptozotocin would play a more effective chemotherapeutic role in their management.

In summary, our data demonstrate a hitherto unrecorded fact about streptozotocin and the human fetal $B$ cell. In vivo the drug does not adversely affect the growth of the fetal pancreas nor its ability to function. In vitro insulin release is not adversely affected by it. This information has potential relevance to the clinical fields of transplantation of human diabetic patients with human fetal pancreas and the treatment of malignant insulinomas with streptozotocin. 
Acknowledgements. We wish to thank Ms. Y. Osborne and Ms. S. Taylor for their technical assistance with the care of the nude mice and insulin extraction of the pancreata and grafts, and Ms. D. Mackie for the isolation of adult mouse islets. This study was supported by grants from the National Health and Medical Research Council of Australia and the Juvenile Diabetes Foundation International.

\section{References}

1. Fujimoto WY, Williams RH (1972) Insulin release from cultured human fetal pancreas. Endocrinology 91: 1133-1136

2. Milner RDG, Ashworth MA, Barson AJ (1972) Insulin release from human fetal pancreas in response to glucose, leucine and arginine. J Endocrinol 52: 497-505

3. Schaeffer LD, Wilder ML, Williams RH (1973) Secretion and content of insulin and glucagon in human fetal pancreas slices in vitro. Proc Soc Exp Biol Med 143: 314-319

4. Hoffman L, Mandel TE, Carter WM, Koulmanda M, Martin FIR (1982) Insulin secretion by fetal human pancreas in organ culture. Diabetologia 23: 426-430

5. Agren A, Andersson A, Björken C, Groth CG, Gunnarsson R, Hellerström C, Lindmark G, Lundqvist G, Petersson B, Swenne I (1980) Human fetal pancreas: culture and function in vitro. Diabetes 29 [Suppl 1]: 64-69

6. Maitland JE, Parry DG, Turtle JR (1980) Perifusion and culture of human fetal pancreas. Diabetes 29 [Suppl 1]: 57-63

7. Junod A, Lambert AE, Orci L, Pictet R, Gonet A, Renold AE (1967) Studies of the diabetogenic action of streptozotocin. Proc Soc Exp Biol Med 126: 201-205

8. Rerup CC (1970) Drugs producing diabetes through damage of the insulin secreting cells. Pharmacol Rev 22: 485-518

9. Wilson JD, Dhall DP, Simeonovic CJ, Lafferty KJ (1986) Induction and management of diabetes mellitus in the pig. Aust J Exp Biol Med Sci 64: 489-500

10. Kushner B, Lazar M, Furman M, Lieberman TW, Leopold IH (1969) Resistance of rabbits and guinea pigs to the diabetogenic effect of streptozotocin. Diabetes 18: 542-544

11. Sandler S, Andersson A (1982) The partial protective effect of the hydroxyl radical scavenger dimethyl urea on streptozotocin-induced diabetes in the mouse in vivo and in vitro. Diabetologia 23: 374-378

12. Eizirik DL, Sandler S, Welsh N, Hellerström C (1988) Preferential reduction of insulin production in mouse pancreatic islets maintained in culture after streptozotocin exposure. Endocrinology 122: $1242-1249$

13. Portha B, Kergoat M (1985) Dynamics of glucose-induced insulin release during the spontaneous remission of streptozotocin diabetes induced in the newborn rat. Diabetes 34:574-579

14. LeDoux SP, Woodley SE, Patton NJ, Wilson GL (1986) Mechanisms of nitrosourea-induced $\beta$-cell damage: Alterations in DNA. Diabetes 35: 866-872

15. Tuch BE, Lissing JR, Suranyi MG (1988) Immunomodulation of human fetal cells by the fungal metabolite gliotoxin. Immunol Cell Biol 66: 307-312

16. Tuch BE (1988) From nude mouse to man. In: Peterson C, Jovanovic L, Formby B (eds) Fetal islet transplantation. Springer, Berlin Heidelberg New York, pp 214-267

17. Tuch BE, Maitland JE, Turtle JR (1984) Culture and perifusion of human fetal pancreas. In: Larner J, Pohl S (eds) Methods in diabetes research, vol 1: Laboratory methods, Part B. J Wiley, New York, pp 153-163

18. Schein PS, Loftus S (1968) Streptozotocin: Depression of mouse liver pyridine nucleotide. Cancer Res 28: 1501-1506

19. Forist AA (1964) Spectrophotometric determination of streptozotocin. Anal Chem 36: 1338-1339

20. Prowse SJ, Simeonovic CJ, Lafferty KJ, Bond BC, Magi CE, Mackie D (1984) Allogenic islet transplantation without recipient immunosuppression. In: Larner J, Pohl S (eds) Methods in diabetes research, vol 1: Laboratory methods, Part B. J Wiley, New York, pp 253-269
21. Dixon WJ (1985) BMDP statistical software. Uni California Press, Berkeley

22. Gillies MC, Mandel TE (1987) Spontaneous reversion to normoglycaemia in mice made diabetic with streptozotocin. Proc Aust Diab Soc 34

23. Van Assche FA (1970) The foetal endocrine pancreas: A quantitative morphologic approach. In: Ortho Pharmaceutica Thesis. Belgium, Katholiek Uni

24. Karunanayake EH, Hearse DJ, Mellows G (1976) Streptozotocin: Its excretion and metabolism in the rat. Diabetologia 12: 483-488

25. Cantenys D, Portha B, Dutrillaux MC, Hollande E, Roze C, Picon L (1981) Histogenesis of the endocrine pancreas in newborn rats after destruction by streptozotocin: An immunocytochemical study. Virch Arch Cell Pathol 35: 109-122

26. Hayek A, Barela TD, Wogenrich FJ, Guardian CM (1985) Fetal rat insulin deficiency following maternal administration of streptozotocin. Proc Soc Exp Biol Med 180: 209-213

27. Schein P, Kahn R, Gorden P, Wells S, DeVita VT (1973) Streptozotocin for malignant insulinomas and carcinoid tumor: Report of eight cases and review of the literature. Arch Intern Med 132: 555-561

28. Ledoux SP, Wilson GL (1984) Effects of streptozotocin on a clonal isolate of rat insulinoma cells. Biochem Biophys Acta 804: 387-392

29. Ammon HPT, Bumiller G, Düppenbecker H, Heinze E, Lutz S, Verspohl EJ (1983) Pentose phosphate shunt, pyridine nucleotides, glutathione, and insulin secretion of fetal islets. Am J Physiol 244: E354-360

30. Akpan JO, Wright PH, Dulin WE (1982) Effect of diabetogenic nitrosoureas upon the activity of the pentose phosphate shunt in isolated islets. Acta Diabetol Lat 19:37-47

31. Yamamoto $H$, Uchigata $Y$, Okamoto $H$ (1981) Streptozotocin and alloxan induce DNA strand breaks and poly (ADP-ribose) synthetase in pancreatic islets. Nature 294: 284-286

32. Wilson GL, Hartig PC, Patton NI, LeDoux SP (1988) Mechanisms of nitrosourea-induced $\beta$-cell damage: Activation of poly (ADP-ribose) synthetase and cellular distribution. Diabetes 37: 213-216

33. Nielsen JH (1984) Destruction of insulin producing cells by diabetogenic agents in vitro: Differences in susceptibility and mechanisms of action. Immunol Diabet 84: 86

34. Weiss RB (1982) Streptozotocin: A review of its pharmacology, efficacy, and toxicity. Cancer Treat Rep 66: 427-438

35. Tuch BE, Osgerby KJ, Turtle JR (1988) Human fetal pancreas grafted into non-diabetic nude mice normalizes blood glucose levels once diabetes is induced. Transplantation 46: 608-611

36. Broder LE, Carter SK (1973) Pancreatic islet cell carcinoma. II. Results of therapy with streptozotocin in 52 patients. Ann Intern Med 79: 108-118

37. Moertel CG, Hanley JA, Johnson LA (1980) Streptozotocin alone compared with streptozotocin plus fluorouracil in the treatment of advanced islet-cell carcinoma. N Eng J Med 303: 1189-1194

38. Frerichs H, Creutzfeldt W (1976) Hypoglycaemia. I. Insulin secreting tumours. Clin Endo Metab 5: 747-767

39. Berger M, Bordi C, Cüppers HJ, Berchtold P, Gries FA, Münterfering H, Sailer R, Zimmermann H, Orci L (1983) Functional and morphologic characterization of human insulinomas. Diabetes 32: 921-931

40. Otonkoski T, Andersson S, Knip M, Simell O (1988) Maturation of insulin response to glucose during human fetal and neonatal development: Studies with perifusion of pancreatic isletlike cell clusters. Diabetes 37:286-291

Received: 16 November 1988

and in revised form: 3 May 1989

Dr. B.E.Tuch

Department of Medicine

University of Sydney

New South Wales 2006

Australia 